\title{
COMMENT
}

\section{Paradigms of Poverty: A Reply to Peter Townsend and Hugh McLachlan.}

\section{JOHN VEIT-WILSON*}

To answer first the comment by Hugh McLachlan, I confess that my attempt to condense his densely argued paper into one sentence may have been too brutal. The last sentence of his third paragraph conveys the meaning I intended to quote. The rest of his comment appears to be addressed to Peter Townsend and not to me.

In replying to Peter Townsend, I want to emphasize that I acknowledge with respect that for more than thirty years he has probably done more than any other person on the international scene to develop sociological theories and methods of poverty research and an understanding of their relations with social policies. During this time he has maintained unchanged views on Rowntree's concepts of poverty, views which I believe are based on a misreading of Rowntree. The aspects of poverty which Townsend was concerned with in the 1950s were not the same as those which exercised the public at the end of the last century when Rowntree worked. I believe the key to understanding their differences lies in a more historically informed reading of Rowntree - and of Townsend. It really is not a matter for dispute that the public issue when Rowntree first worked was not 'what is poverty?' but 'why are the many poor?'. What was then called 'poverty', which I represent as $\Sigma P$ and which Townsend and I would now call 'deprivation', was conventionally defined and described in terms of lifestyle. But in the post-Beveridge Report era in which Townsend developed his ideas, the prevailing preoccupation was the adequacy or otherwise of the National Assistance scales; 'poverty' had become defined as lack of money. Townsend's perception of Rowntree's intentions is coloured by Townsend's own valid concerns projected backwards to a different era.

Townsend asserts that I have failed to uncover Rowntree's real intentions, and that ideally Rowntree wanted to measure $\Sigma$ P in cash terms, but he was prevented on methodological grounds and therefore used lifestyle as a proxy for income. Selective quotation and exegesis can be a game, but the policy implications of this issue are important and so

\footnotetext{
- Head of the School of Applied Social Science, Newcastle upon Tyne Polytechnic.
} 
I hope I'll be forgiven for spelling things out. Readers must judge for themselves and not be led by Townsend or me. They must see if they can discover the passage in which Rowntree says that, as Townsend puts it, he intended 'both primary and secondary poverty to be operationally measured in terms of the subsistence standard which he set out carefully in pages 86-110 of his first book' (my italics). On the contrary, what Rowntree wrote was: 'Before we can arrive at an estimate of the number of those who are living in "primary" poverty in York, we must ascertain what income is required by families of different sizes to provide the minimum of food, clothing, and shelter needful for the maintenance of merely physical health' (1901, p.87). Then, on page 115, comes the passage Townsend quotes, headed "What is the Extent of "Secondary" Poverty in York?'. Immediately following this passage, Rowntree starts a new paragraph "The number of persons living in "secondary" poverty was ascertained in the following way. The investigator ...' - and then comes the description of identifying poverty as 'obvious want and squalor'. There is absolutely no evidence for Townsend's assertion that, following the paragraph Townsend quotes, Rowntree 'went on to explain that instead of pursuing this ideal procedure he adopted an alternative procedure by which his investigators noted down cases of "obvious want and squalor" ...' No such explanation exists.

Townsend supports his assertion by suggesting that if Rowntree 'had been intending to adopt a criterion different from income' (to define $\Sigma$ P) 'I believe he would have discussed it at some length'. Rowntree did discuss primary poverty at length (nearly thirty pages) because it was a new and problematic concept for his readers. If he had intended to measure secondary poverty or $\Sigma \mathrm{P}$ in the same way, by income, he would no doubt have done so at similar length. But why should Rowntree discuss at any length a concept or criterion of poverty which was completely acceptable and unproblematic to his contemporaries? The fact that Rowntree did not discuss the criterion of $\Sigma \mathrm{P}$ (he merely describes it in several places as 'obvious want and squalor') seems to suggest that Townsend has got it the wrong way round and is thinking anachronistically.

The best guide to Rowntree's intentions is, of course, what he himself wrote about them. On page vi of the Introduction to Poverty - a Study of Town Life (1901) Rowntree writes:

Amongst other questions upon which I desired to obtain information were the following: What was the true measure of the poverty in the city, both in extent and depth? How much of it was due to insufficiency of income and how much to improvidence? How many families were sunk in a poverty so acute that its members suffered from a chronic insufficiency of food and clothing? 
Now, if Rowntree intended to measure $\Sigma$ P in cash terms as Townsend asserts, he could not have phrased his intentions in this way. In simple logic, the category 'poverty' in the statement quoted is caused partly by lack of income and partly by improvidence. Improvidence is not an economic but a social concept: even rich people may be improvident. You can't put a price on improvidence even if (for heuristic and not prescriptive reasons, as my paper shows) Rowntree did so for 'merely physical efficiency'.

Rowntree gives further evidence of his intentions on page viii of the Introduction. Immediately following the well known description of the two classes of poverty (primary - P1 and secondary - P2), Rowntree writes that:

In order to ascertain the proportion of the former, (my italics to emphasize that he refers to P1 but not 2) it was necessary, in addition to knowing the earnings of each family, to arrive at the minimum sum necessary to maintain families of various sizes in a state of physical efficiency.

There is no reference here or anywhere else to an income measure for $\mathrm{P} 2$ or $\Sigma \mathrm{P}$, although there easily could have been if Townsend's hypothesis were correct, since Rowntree had information on the earnings of every working class household in York, including therefore all those identified as being in P2.

Rowntree's Chapter Three, 'The Standard of Life', is devoted to the analysis of the household incomes of the whole York working class, including the 43.4 per cent of it who were poor. If he really had intended to measure $\Sigma \mathrm{P}$ in cash terms, or even to derive income correlates from the households with poor lifestyles, he could and would have done it with the data he had collected. But he did not do so, because it was irrelevant to his concern with the causes of poverty. On pages 75-76 of my paper I quoted from Rowntree's thirty page pamphlet in which he defended his methods in great detail against Mrs. Bosanquet's criticisms, and where he is absolutely explicit about the distinction between P1 as a money measure "while the fixing of my "secondary" poverty line depends upon observations regarding the conditions under which the families were living' (1903, p.20). Rowntree describes how he 'was able either to state or to make a careful estimate of the wages of each wage-earner in York' (1903, p.13). Taken together, Rowntree's unequivocal statements make Townsend's hypothesis look highly implausible.

So how can we understand Townsend's persistent conviction that Rowntree's definition of $\mathrm{P} 2$ was meant to be a guide to a money measure 
of $\Sigma$ P ? I believe the answer lies in Rowntree's propensity for ambiguity referred to in my paper $(1986, \mathrm{pp} .72-73,94)$. The nub of the issue is that in describing P1 and P2 Rowntree uses a form of words which leaves some readers uncertain if he refers to the characteristics of poor people's spending behaviour or the level of income they have to spend. In the case of $\mathrm{P} 1$, the money they have is less than what is needed for 'merely physical efficiency'. But in the case of $\mathrm{P} 2$, the families have incomes more than this. Rowntree does not tell us how much more they have (which he could have done), nor how much they should have; he simply implies that they do not achieve merely physical efficiency because they spend their money on other things besides what is needed for merely physical efficiency - food, clothing, fuel and rent. However, Townsend's interpretation of this fails to lead to his desired conclusions. First he writes of $\mathrm{P} 2$ as 'insufficient expenditure ... whatever the income' (my italics), which suggests $\mathrm{P} 2$ cannot be defined in cash terms. He then refers to the 'ideal procedure' implying an income criterion of P2. But Townsend's 'crucial' passage means simply this: if Rowntree had wanted to find out why the families in P2 were failing to achieve what Townsend calls sufficient expenditure on the subcategories of the P1 standard (i.e. the elements of merely physical efficiency) while having incomes higher than Rowntree had calculated were necessary for P1, then Rowntree would have had to carry out budget studies on their expenditure patterns to see where the money was going instead on 'other expenditure, either useful or wasteful' (1901, p.115). But it is common knowledge that studies of how the poor spend their inadequate incomes is no guide to how much income they need in order not to be poor. Rowntree's impracticable interest in budget studies of P2 families was no more than part of his attempt to answer the contemporary question of whether poverty as lifestyle was caused by insufficiency of income or by improvidence. Thus on the basis of both Rowntree's and Townsend's writings one cannot confidently accept Townsend's supposition that Rowntree intended either P2 or what he called the poverty line to be ideally defined in cash terms.

What were these 'useful or wasteful expenditures'? Examination of Rowntree's famous and much quoted description of what life on the P1 level means (1901, pp.133-134) shows the many excluded items which are indispensable for a normal social life, items which in the values of the time might have been considered as useful (such as fares, subscriptions to sick clubs or trade unions, savings for unemployment, postage stamps) or wasteful (such as tobacco or beer) or somewhere in between (children's pocket money, newspapers, church contributions, savings for funeral expenses). Rowntree states that if the families in P1 
spend anything on items such as these 'the extra expenditure involved is met, and can only be met, by limiting the diet; or, in other words, by sacrificing physical efficiency' (1901, p.134). We see here, too, the preoccupation with studying how the poor spend their money. Thus, pace Townsend (1979, p.239) and many others, P2 did not mean mismanagement or improvidence even if some of the poor were inefficient managers; and I quoted Rowntree at length to show that he did not believe that anyone could actually live a social life on the P1 level. It follows from this logically that a family might have an income above P1 and be completely 'provident' but still be unable to avoid the appearances of poverty: it would therefore be classified as $\mathrm{P} 2$.

I am grateful to Peter Townsend for providing this opportunity to clarify Rowntree's meanings, and I hope he will now join the group of those, including Rowntree's biographer Asa Briggs, who realize that Rowntree was not the forebear of the Thatcherite approach to Supplementary Benefit but of people who, like Townsend himself, use a relativistic lifestyle concept of poverty (or deprivation) and promote state action on low wages, family benefits, health, housing and employment to combat it.

\section{REFERENCES}

A. Briggs (1961), Social Thought and Social Action: A Study of the Work of Seebohm Rowntree, Longman, London.

B.S. Rowntree (1901), Poverty: A Study of Town Life, Macmillan, London.

B.S. Rowntree (1903). The 'Poverty Line': A Reply (no publisher or date printed ; Briggs [1961] gives 1903 but British Library of Political and Economic Science catalogue gives 1901).

P. Townsend (1979), Poverty in the United Kingdom. Penguin, Harmondsworth.

J.H. Veit-Wilson (1986), 'Paradigms of Poverty: A Rehabilitation of B.S. Rowntree'. Journal of Social Policy. Vol. 15. No. 1, pp.69-99. 